Critical oxygen concentration in hydrogenated amorphous silicon solar cells dependent on the contamination source

Jan Woerdenweber, Tsvetelina Merdzhanova, Helmut Stiebig, Wolfhard Beyer, and Aad Gordijn

Citation: Appl. Phys. Lett. 96, 103505 (2010); doi: 10.1063/1.3357424

View online: https://doi.org/10.1063/1.3357424

View Table of Contents: http://aip.scitation.org/toc/apl/96/10

Published by the American Institute of Physics

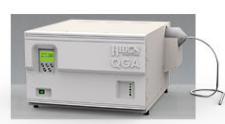

Gas Analysis

dynamic measurement of reaction gas streams

cetayysis and thermal analysis

' molecuar beam sudes

, fermentation, enviromentental and ecological studies

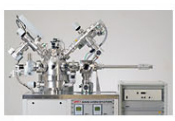

Surface Science

UHVTPD

SIMS

end point detection in ion beam etch emental imaging - surface mapoing

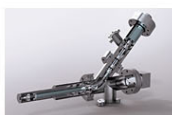

Plasma Diagnostics

- plasma source characterization

etch and deposition process reac

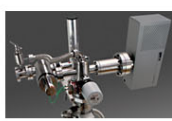

Vacuum Analysis

partial pressure measurement and control

of process gases

rocess control

vacuum diagnostics 


\title{
Critical oxygen concentration in hydrogenated amorphous silicon solar cells dependent on the contamination source
}

\author{
Jan Woerdenweber, ${ }^{1, a)}$ Tsvetelina Merdzhanova, ${ }^{1}$ Helmut Stiebig, ${ }^{2}$ Wolfhard Beyer, ${ }^{1,2}$ and \\ Aad Gordijn ${ }^{1}$ \\ ${ }^{1}$ IEF5-Photovoltaik, Forschungszentrum Jülich, D-52425 Jülich, Germany \\ ${ }^{2}$ Malibu GmbH \& Co. KG, Böttcherstr. 7, D-33609 Bielefeld, Germany
}

(Received 19 November 2009; accepted 16 February 2010; published online 9 March 2010)

\begin{abstract}
For hydrogenated amorphous silicon (a-Si:H) solar cells, the critical concentration of a given impurity defines the lowest concentration which causes a decay of solar cell efficiency. Values of $2-5 \times 10^{19} \mathrm{~cm}^{-3}$ are commonly found for the critical oxygen concentration $\left(\mathrm{C}_{\mathrm{O}}^{\text {crit }}\right)$ of a-Si:H. Here we report a dependence of $\mathrm{C}_{\mathrm{O}}^{\text {crit }}$ on the contamination source. For state-of-the-art a-Si:H solar cells prepared at the same plasma deposition conditions, we obtain with a (controllable) chamber wall leak $\mathrm{C}_{0}^{\text {crit }} \sim 2 \times 10^{19} \mathrm{~cm}^{-3}$ while for a leak in the gas supply line a higher $\mathrm{C}_{\mathrm{O}}^{\text {crit }}$ of $\sim 2$ $\times 10^{20} \mathrm{~cm}^{-3}$ is measured. No such dependence is observed for nitrogen. (C) 2010 American Institute of Physics. [doi:10.1063/1.3357424]
\end{abstract}

The critical oxygen concentration $\mathrm{C}_{\mathrm{O}}^{\text {crit }}$ in thin-film silicon solar cells defines the concentration of oxygen in the hydrogenated amorphous $(\mathrm{a}-\mathrm{Si}: \mathrm{H})$ and microcrystalline $(\mu \mathrm{c}-\mathrm{Si}: \mathrm{H})$ absorber layers up to which the cell parameters like efficiency $\eta$ and fill factor (FF) remain constant. At higher oxygen concentrations, the solar cell parameters decay. Various authors have investigated the insertion of oxygen right into the reactor. ${ }^{1-7}$ Quite similar critical oxygen concentrations $\mathrm{C}_{\mathrm{O}}^{\text {crit }}$ of $2 \times 10^{19} \mathrm{~cm}^{-3}$ were found for a-Si:H and $\mu \mathrm{c}-\mathrm{Si}: \mathrm{H}^{6,7}$ while some authors ${ }^{1}$ reported higher values. Studies of films and solar cells showed that the major reason for the decay of solar cell parameters for an oxygen concentration $\mathrm{C}_{\mathrm{O}}>\mathrm{C}_{\mathrm{O}}^{\text {crit }}$ is some doping action of incorporated oxygen, shifting the Fermi level toward the conduction band resulting into a distorted electric field within the absorber layer. ${ }^{2}$ When incorporated in three- or fourfold coordination to silicon, oxygen is considered a donor in $\mathrm{Si}: \mathrm{H}^{2-5}$ From the rather high critical concentration of $\mathrm{C}_{\mathrm{O}}^{\mathrm{crit}} \geq 2 \times 10^{19} \mathrm{~cm}^{-3}$ it can be concluded, however, that only a very small fraction of incorporated oxygen is in a doping configuration. By comparison with phosphorus doping, one may estimate that at the critical oxygen concentration $\sim 10^{16} \mathrm{~cm}^{-3}(\sim 0.5 \%$ o) oxygen atoms are in doping configuration. The predominant part of incorporated oxygen is expected to be in the nondoping twofold coordination to silicon, as in $\mathrm{SiO}_{2}$.

The critical oxygen concentration is of importance for production issues of thin-film $\mathrm{Si}$ solar cells since reduced vacuum and gas purity requirements may be an important cost factor. Here we studied the influence of the position of the oxygen leak on the critical oxygen concentration. It is found that feeding the oxygen into the process gas supply line results in a considerably higher critical oxygen concentration than using a chamber wall leak.

A multichamber PECVD (plasma-enhanced chemical vapor deposition) system with capacitive coupled parallel plate electrodes with an excitation frequency of $13.56 \mathrm{MHz}$ was used for the preparation of thin-film a-Si:H solar cells. Commercial Asahi Type $\mathrm{U}\left(\mathrm{SnO}_{2}: \mathrm{F}\right)$ transparent conductive

\footnotetext{
a) Author to whom correspondence should be addressed. Electronic mail: j.woerdenweber@fz-juelich.de.
}

oxide coated $10 \times 10 \mathrm{~cm}^{2}$ glasses served as substrates. The deposition conditions for the i-layers were "high flow, high pressure." ${ }^{, 9}$ This regime had process gas flows of (7.8/360) SCCM $\left(\mathrm{SiH}_{4} / \mathrm{H}_{2}\right)$, a deposition pressure of 10 Torr and a heater temperature of $\sim 200{ }^{\circ} \mathrm{C}$. The deposition rates were $0.4-0.5 \mathrm{~nm} / \mathrm{s}$. The thickness of the i-layers was $\sim 350 \mathrm{~nm}$. Thermally evaporated silver was used as a back reflector and defined the solar cell area of $1 \mathrm{~cm}^{2}$. To simulate chamber leakages, poor vacuum conditions and/or outgassing the contamination gases (purity 5.0) were introduced by a controllable leak at the chamber wall. A controllable leak in the gas pipe was applied for the simulation of gas pipe leakages and contaminated process gases. The location of both leaks can be seen in Fig. 1. For the chamber wall leak its distance to the plasma zone was approximately $\mathrm{d}_{\mathrm{CWL}}=25 \mathrm{~cm}$. To avoid unintended contamination, the process gases $\mathrm{SiH}_{4}$ and $\mathrm{H}_{2}$ (both with purity 6.0) passed through a gas purifier. The dis-

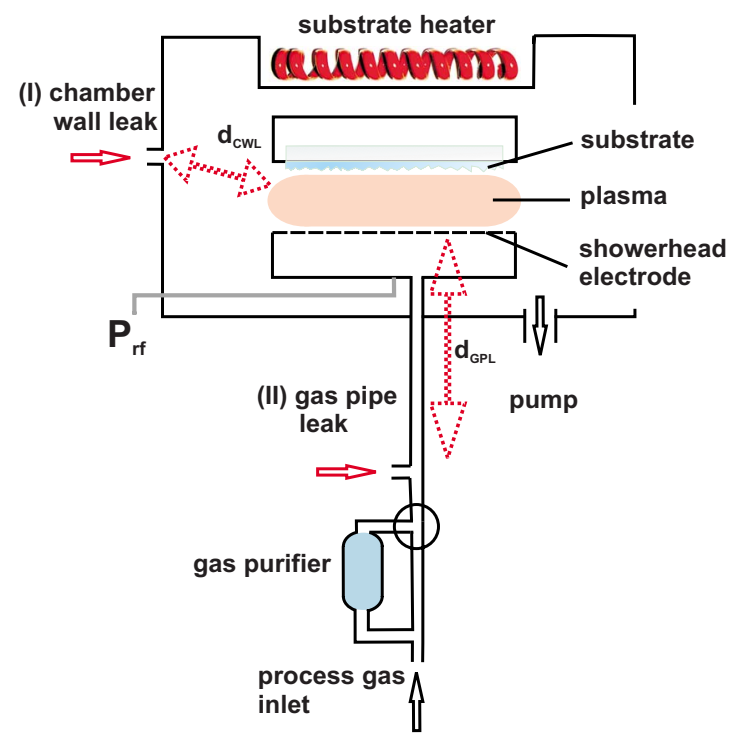

FIG. 1. (Color online) Schematic picture of the PECVD deposition chamber used for the deposition of the contaminated intrinsic absorber layers. The two leaks applied are a chamber wall leak (I) and a gas pipe leak (II) situated at a distance of $\mathrm{d}_{\mathrm{CWL}}=25 \mathrm{~cm}$ and $\mathrm{d}_{\mathrm{GPL}}=50 \mathrm{~cm}$ from the plasma zone, respectively. 


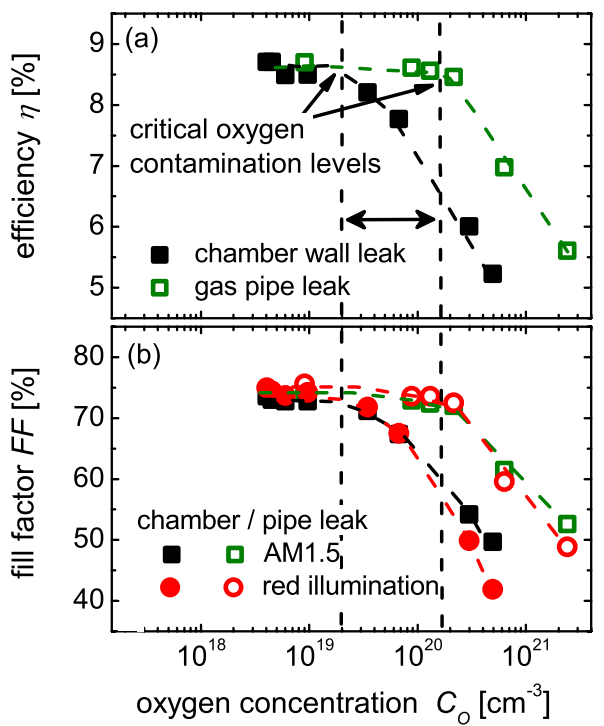

FIG. 2. (Color online) Solar cell efficiency $\eta$ (a) and FF (b) as a function of the oxygen concentration in the i-layer varied by controllable chamber (filled symbols) and gas pipe (open symbols) oxygen leaks. The fill factor was measured under AM1.5 and under red illumination.

tance of the gas pipe leak (GPL) to the showerhead electrode, i.e., to the plasma zone, was $\mathrm{d}_{\mathrm{GPL}}=50 \mathrm{~cm}$. Here, no gas purifier was used. Further details of this experiment are given elsewhere. ${ }^{9}$ After deposition the $\mathrm{p}-\mathrm{i}-\mathrm{n}$ solar cells were characterized by I/V measurements under AM1.5 illumination (Wacom, class A solar simulator, $100 \mathrm{~mW} / \mathrm{cm}^{2}$ ) at $25^{\circ} \mathrm{C}$. Additional filters (BG 7 \& OG 590) were applied. Impurity concentrations were measured by secondary ion mass spectrometry (SIMS) using a quadrupole instrument (Atomika 4000). ${ }^{10}$

In Fig. 2 the initial solar cell efficiency $\eta[$ Fig. 2(a)] and FF [Fig. 2(b)] are plotted as a function of the oxygen concentration for contaminated cells. For the chamber wall leak, $\eta$ and FF, start to decrease at $\sim 2 \times 10^{19}$ atoms $/ \mathrm{cm}^{3}$. A shift of the critical oxygen contamination level by about one order of magnitude (from $\sim 2 \times 10^{19}$ to $\sim 2 \times 10^{20}$ atoms $/ \mathrm{cm}^{3}$ ) is observed when the gas pipe leak was applied. The shortcircuit current $\mathrm{j}_{\mathrm{SC}}$ and the open circuit voltage $\mathrm{V}_{\mathrm{OC}}$ remained constant at $\sim 13 \mathrm{~mA} / \mathrm{cm}^{2}$ and $\sim 900 \mathrm{mV}$, respectively, irrespective of the oxygen concentration. Only the most contaminated films show slight losses in $\mathrm{j}_{\mathrm{SC}}$ under red illumination, presumably caused by the worsened bulk carrier extraction and alloying effects. Light-soaking (1000 h, $50{ }^{\circ} \mathrm{C}$, open circuit conditions) was found not to change the critical oxygen concentration.

We investigated the effect of a gas pipe leak also for nitrogen but, as demonstrated in Fig. 3, no difference to a chamber leak is observed in this case. A critical nitrogen concentration of $4 \times 10^{18}$ atoms $/ \mathrm{cm}^{3}$ is seen, as reported earlier. ${ }^{7}$ Also for nitrogen incorporation, the decay in solar cell efficiency is attributed to doping effects. ${ }^{2}$ Thus the present solar cell results show that changes in the incorporation ratio of impurities in doping and non-doping configuration by using different contamination sources occur only for oxygen, not for nitrogen. Measurements of dark conductivity of i-layers prepared with oxygen and nitrogen contamination confirm these solar cell results.

As well known, the incorporation of certain atomic configurations in a-Si alloys during plasma deposition may de-

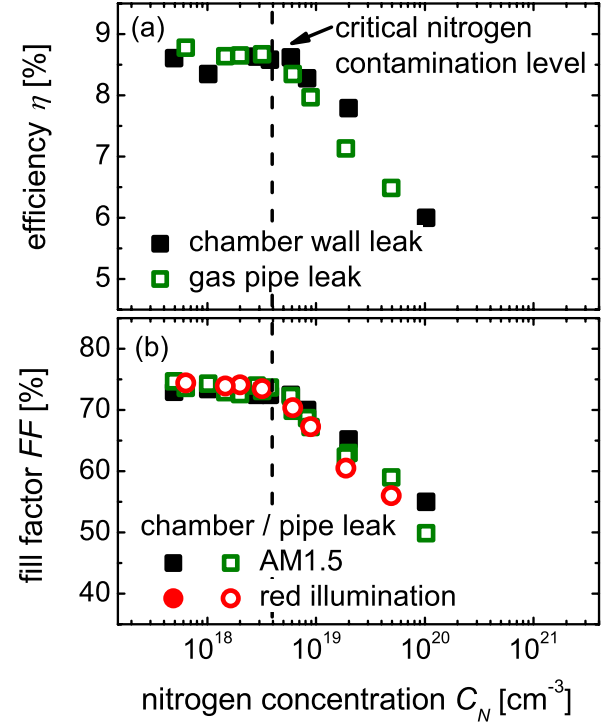

FIG. 3. (Color online) Solar cell efficiency $\eta$ (a) and FF (b) as a function of the nitrogen concentration in the i-layer, varied by controllable chamber (filled symbols) and gas pipe (open symbols) nitrogen leaks.

pend on the type of precursor species. For example, molecules containing $\mathrm{Si}-\mathrm{C}$ or $\mathrm{Si}-\mathrm{N}$ groups are likely to cause $\mathrm{Si}-\mathrm{C}$ and $\mathrm{Si}-\mathrm{N}$ groups in the material if the plasma power is below the level where complete fractionation of precursor species of high binding energy occurs. ${ }^{11}$ The binding energies of $\mathrm{Si}-\mathrm{C}$ and $\mathrm{Si}-\mathrm{N}$ are 4.5 and $4.6 \mathrm{eV}$, respectively and exceed that of $\mathrm{Si}-\mathrm{Si}(\approx 2.5 \mathrm{eV})$ considerably. ${ }^{12}$ For $\mathrm{Si}-\mathrm{O}$, the binding energy is even higher $(8.3 \mathrm{eV}){ }^{12}$ Thus, a source for oxygen atoms incorporated in a non-doping configuration could be precursor molecules in the gas phase with $\mathrm{Si}-\mathrm{O}-\mathrm{Si}$ bonding configuration like siloxane molecules. A likely explanation of the observed results then is that in the gas pipe leak such molecules form due to reaction of oxygen with silane outside of the plasma region. Apparently, much less of such molecules would form for the chamber wall leak, possibly because here the oxygen encounters a more silanedepleted reaction gas with lower probability of siloxane-type molecules to form. A much faster entering of oxygen of the plasma zone could also lead to a reduction of the reaction probability of oxygen and silane. It is possible, however, that oxygen from the chamber wall leak reacts with atomic or molecular hydrogen, which are predominant gas species in a depleted silane plasma next to the plasma zone, forming $\mathrm{OH}$ or $\mathrm{H}_{2} \mathrm{O}$. Both these species may be speculated to be precursors for the incorporation of oxygen in a doping configuration in a-Si:H, in analogy to a-Ge:H where the incorporation of $\mathrm{OH}$ complexes is known to lead to high n-type doping. ${ }^{13}$ Due to the much lower reactivity of nitrogen with silane or hydrogen, ${ }^{14}$ no difference for nitrogen incorporation from different types of leaks is expected, as observed experimentally.

In summary, we have investigated for a-Si:H solar cells the incorporation of impurities (oxygen and nitrogen) introduced together with the process gases (gas pipe leak) or through a chamber leak. It is demonstrated that the critical oxygen concentration in these solar cells depends on the contamination source. The results show a critical oxygen concentration for the gas pipe leak, that is enhanced, compared to the chamber wall leak, by about one order of magnitude up to $2 \times 10^{20}$ atoms $/ \mathrm{cm}^{3}$. A high reaction probability of 
oxygen and silane in the gas pipe outside of the plasma is suggested to promote the formation of electrically inactive twofold-coordinated oxygen in the i-layer of the solar cells. State-of the-art a-Si:H solar cells were fabricated with a gas pipe leak at the high oxygen concentration of $2 \times 10^{20}$ atoms $/ \mathrm{cm}^{3}(\approx 0.5$ at. $\%)$. For nitrogen the decrease in solar cell performance is independent of the sources of contamination. This can be explained by the lack of reactivity of nitrogen with silane outside of the plasma zone.

The authors thank R. Schmitz, A. Mueck, L. Niessen, U. Zastrow, R. van Aubel, and T. Zimmermann for contributions to this work. Part of the work was financed by the NRW Project No. EN/1008B “TRISO”.

${ }^{1}$ B. Rech, C. Beneking, S. Wieder, U. Zastrow, F. Birmans, W. Appenzeller, O. Kluth, H. Stiebig, J. Fölsch, H. Wagner, W. Frammelsberger, R. Geyer, P. Lechner, H. Rübel, H. Shade, and H. Maurus, Proceedings of the 2nd World Conference and Exhibition on Photovoltaic Solar Energy Conversion, 1998 , p. 391.

${ }^{2}$ T. Kinoshita, M. Isamura, Y. Hishikawa, and S. Tsuda, Jpn. J. Appl. Phys., Part 1 35, 3819 (1996).

${ }^{3}$ A. Morimoto, M. Matsumoto, M. Yoshita, M. Kumeda, and T. Shimizu, Appl. Phys. Lett. 59, 2130 (1991).

${ }^{4}$ T. Shimizu, M. Matsumoto, M. Yashita, M. Iwami, A. Morimoto, and M. Kumeda, J. Non-Cryst. Solids 137-138, 391 (1991).
${ }^{5}$ M. Isomura, T. Kinoshita, and S. Tsuda, Appl. Phys. Lett. 68, 1201 (1996).

${ }^{6}$ T. Kilper, W. Beyer, G. Bräuer, T. Bronger, R. Carius, M. N. van den Donker, D. Hrunski, A. Lambertz, T. Merdzhanova, A. Mück, B. Rech, W. Reetz, R. Schmitz, U. Zastrow, and A. Gordijn, J. Appl. Phys. 105, 074509 (2009).

${ }^{7}$ J. Woerdenweber, T. Merdzhanova, R. Schmitz, A. Mueck, U. Zastrow, L. Niessen, A. Gordijn, R. Carius, W. Beyer, H. Stiebig, and U. Rau, J. Appl. Phys. 104, 094507 (2008).

${ }^{8}$ W. Beyer and H. Overhof, Semiconductors and Semimetals, edited by J. I. Pankove (Academic, New York, 1984), Vol. 21, p. 257.

${ }^{9}$ J. Woerdenweber, T. Merdzhanova, R. Schmitz, A. Mueck, D. Hrunski, U. Zastrow, L. Niessen, A. Gordijn, H. Stiebig, W. Beyer, and U. Rau, Proceedings of the 23rd European Photovoltaic Solar Energy Conference, Valencia, Spain (WIP, Munich, 2008), p. 2121.

${ }^{10}$ A. Mueck, U. Zastrow, O. Vetterl, and B. Rech, Secondary Ion Mass Spectroscopy-SIMS XII, Proceedings of the 12th International Conference on Secondary Ion Mass Spectroscopy, edited by A. Benninghoven, P. Bertrand, H. N. Migeon, and H. W. Werner (Elsevier, New York, 2000), p. 689.

${ }^{11}$ W. Beyer and H. Mell, in Disordered Materials, edited by M. A. Kastner, G. A. Thomas, and S. R. Ovshinsky (Plenum, New York, 1987), p. 641.

${ }^{12}$ J. A. Kerr and A. F. Trotman-Dickenson, in CRC Handbook of Chemistry and Physics, edited by R. C. Weast (CRC, West Palm Beach, 1977), p. F-219.

${ }^{13}$ B. Schröder, A. Annen, T. Drüsedau, H. Freistedt, P. Deàk, and H. Oechsner, Appl. Phys. Lett. 62, 1961 (1993).

${ }^{14}$ Material Safety Data Sheet, Nitrogen-Silane Mixtures (Chemical Safety Associates, La Mesa, CA, 2002). 